\title{
Multi-level governance application to a shared river basin
}

\section{Aplicação da Governança Multinível em uma bacia hidrográfica compartilhada}

\author{
Wanessa Dunga de Assis* (i), Márcia Maria Rios Ribeiro ${ }^{1}$ (1) \& Simone Rosa da Silva² (1) \\ ${ }^{1}$ Universidade Federal de Campina Grande, Campina Grande, PB, Brasil \\ ${ }^{2}$ Escola Politécnica da Universidade de Pernambuco, Recife, PE, Brasil \\ E-mails: w_dunga@hotmail.com (WDA),marcia.ribeiro@ufcg.edu.br (MMRR), simonerosa@poli.br (SRS)
}

Received: November 08, 2019 - Revised: July 25, 2020 - Accepted: July 27, 2020

\begin{abstract}
Water governance systems must be effective in establishing policies capable of guiding decision making. Their framework needs to weigh the intrinsic complexity of inter-scale and multi-level interactions. Aspects such as decentralization and stakeholder engagement are pillars to be considered. In shared river basins (international or national), there are challenges to overcome since there is a need for managing water at different scales and multiple levels. This study aims to analyse the degree of implementation of the National Water Resources Policy in a shared federal basin in Brazil (the São Francisco River Basin) considering the basin as a whole (macro level) and its micro level (the 34 sub-basins that compose it). Multi-level interrelationships in the implementation of water policy are analysed. To this end, OECD Water Governance Principle 2 ("Manage water at the appropriate scales") is considered as the basis for this analysis. An adaptation of the OECD Water Governance Indicator Framework methodology is used to classify the 34 sub-basins at different stages of water policy implementation. The outcomes indicate deficiencies in the process of water policy implementation in sub-basins. There is a need for better interactions at the federal, state and river basin levels to strengthen the governance system.
\end{abstract}

Keywords: Water resources policy; Water domains; Management instruments.

\section{RESUMO}

Sistemas de governança de água devem ser eficientes em estabelecer políticas capazes de nortear a tomada de decisão. Os arcabouços precisam ponderar a complexidade intrínseca das interações interescala e multinível. Aspectos como descentralização e comprometimento entre as partes interessadas são pilares a serem considerados. Existem desafios a serem vencidos em bacias compartilhadas (nacionais ou internacionais) uma vez que há a necessidade de gerenciar a água em diferentes escalas e múltiplos níveis. Este estudo tem como objetivo analisar o grau de implementação da Política Nacional de Recursos Hídricos em uma bacia federal compartilhada (a Bacia Hidrográfica do Rio São Francisco) no seu nível macro e no nível micro (as 34 sub-bacias que a compõe). São analisadas as interrelações multiníveis na implementação da política hídrica como balizador da governança da água. Para tal, considera-se o Princípio 2 da Governança da Água da OECD (Gerenciar a água em escalas apropriadas) como fundamento para essa análise. Uma adaptação da metodologia do Quadro de Indicadores da Governança da Água é usada para classificar as 34 sub-bacias em distintos estágios de implementação da política hídrica. Os resultados apontam para deficiências no processo de implementação da política em sub-bacias. Há necessidade de melhores interações nos níveis federal, estadual e das bacias hidrográficas a fim de fortalecer o sistema de governança.

Palavras-chave: Política de recursos hídricos; Domínio da água; Instrumentos de gestão. 


\section{INTRODUCTION}

Water governance is based on interdependent arrangements among the political, social, economic and managerial spheres. Such arrangements include the formation, establishment, and implementation of policies, legislation and institutions (formal and informal) to regulate the allocation and distribution of water resources. The targets are divided into multiple scales (Organization for Economic Co-operation and Development, 2015a; Wiek \& Larson, 2012).

Traditional institutional structures have been changed to decentralize the water governance of river basins by aligning the political and social spheres to the environmental one. The idea is to seek collaborative opportunities and potential synergies (Lang et al., 2017; Nielsen et al., 2013), although these structures account for practices that go beyond the hydrological boundaries (Budds \& Hinojosa, 2012).

The complex governance of shared river basins involves interdependence between two countries (international boundaries) or state and local governments (national boundaries) (Empinotti et al., 2018; Morais et al., 2018). The literature is wealthy concerning examples of international transboundary basins. Baranyai (2019), for example, discusses transboundary water governance in the European Union. Thomas (2017) presents the disagreement between India and Bangladesh about cooperation over the Ganges River despite the bilateral treaty that has been in force for 20 years. A discussion related to six African transboundary river basin organizations can be found in Saruchera \& Lautze (2016). Another international transboundary example is the Jordan River Basin which includes areas from Lebanon, Syria, Israel, Palestine, and Jordan (Talozi et al., 2019). The La Plata River Basin is the second largest basin in South America. It includes five countries: Argentina, Bolivia, Brazil, Paraguay, and Uruguay (Ribeiro, 2017a).

Interstate river basins have not been as studied as the international transboundary ones. As pointed out by Garrick et al. (2014)

Federal countries distribute authority between national and state jurisdiction, which complicates water management tradeoffs within rivers basin shared by multiples territories. (Garrick et al., 2014, p. 3)

Decisions made at upper levels depend on national and state organizations to be implemented, although their implementation remains dependent on the local level (watershed) to be accepted, legitimated (Earle \& Neal, 2017) and to form a chain. Authors such as Welling et al. (2012) advocate that the governance of interstate water resources lies on clarifying the roles, rules and accountability of different actors because it creates collective participation, which allows conflict mediation and the solution/ prevention of environmental issues.

Water governance faces the challenge of articulating the participation of the local, state and federal government. This articulation makes the system quite complex, given the relationship between water domains and water resource planning. It is necessary to involve the Federal Government and federation units to plan and manage water resources in river basins where the main river is under federal domain. Such entangled structure results in structural and territorial fragmentation due to decision-makers' limited capacity and lack of definition about their role and competences (Akhmouch, 2012; Ménard et al., 2018; Van Rijswick et al., 2014).

Examples of national shared basin are, mainly, from large territorial countries. In Australia, for example, the Murray-Darling Basin is a hydrologically and institutionally complex basin. It encompasses four states: South Australia, New South Wales, Victoria and Queensland. The Murray-Darling Basin covers one-seventh of the land area of Australia. Agricultural production is the main activity in the region (Hart, 2016a, 2016b). We can also highlight the Mackenzie River Basin, Canada's largest river basin that is located in three provinces, each with its organizational structure to govern water, according to the country's constitution (Morris \& De Loë, 2016). In Brazil, approximately $75 \%$ of its territory consists of interstate basins (Agência Nacional de Águas, 2017). One of them is the São Francisco River Basin (SFRB).

The present study aims to identify the associations and aspects of multi-level governance by investigating the implementation of the Brazilian Water Resources Policy (PNRH) at two levels: São Francisco River Basin (macro-level), which is an interstate river basin of national relevance; and its sub-basins (micro-level).

\section{WATER GOVERNANCE SCALES AND LEVELS}

Water governance spheres can be represented by scales (horizontally) or levels (vertically) (Barbosa et al., 2017) depending on a multidimensional matrix that includes actors, arenas and institutions (Berg, 2016). The term "scale" is used to characterize spatial, temporal, quantitative or analytical dimensions that are used to assess water governance, and the term "levels" to refer to the classes of each scale (Cash et al., 2006). "Levels can be considered as an extension of scale as a graduated range" (Daniell \& Barreteau, 2014, p. 2368). For example, a time scale is used to assess the frequency of precipitation events in a river basin. This scale is divided into different classes: interdecadal, annual, monthly, weekly, daily, hourly, etc.

In Figure 1, two examples of different scales with multiple levels and possible connections are presented.

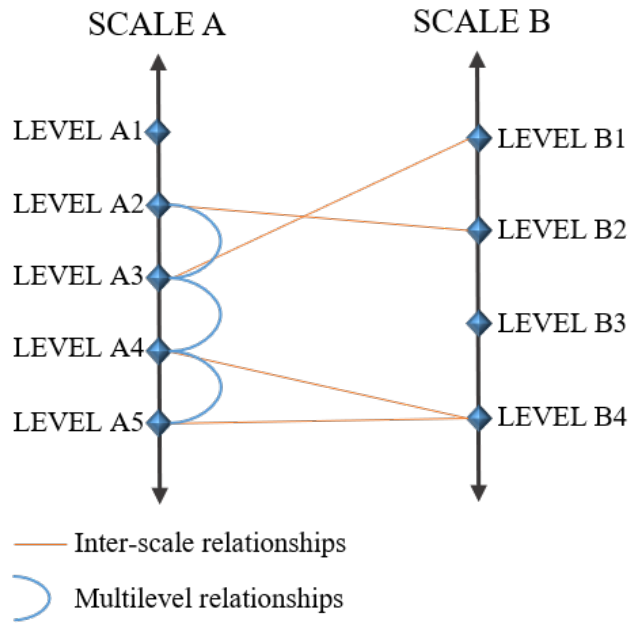

Figure 1. Water Governance Scales and Levels. Source: Elaborated by the authors. Based on Daniell \& Barreteau (2014). 
According to Daniell \& Barreteau (2014), there are eight governance category scales: spatial, temporal, administrative, institutional, managerial, networks, knowledge/information, stakes/ issues. Each of them has a wide variety of defined levels that, although independent, can be combined or work as the basis for the development of new scales - it happens through multi-level interactions and crossed scales. These interactions and crossings result from water flow and physical or material, financial and human flows, from political and social control, as well as from information and knowledge.

River basins emerge as logical management units at the local level, as long as environmental and physical conditions do not limit decisions made about water use and detached from the political, social and economic decisions (Daniell \& Barreteau, 2014; Rathwell \& Peterson, 2012; Woodhouse \& Muller, 2017). According to Akhmouch \& Correia (2016)

While political and administrative structures have to be taken into consideration for the sake of subsidiarity and democratic legitimacy, basin scale and processes have to be necessarily taken into consideration as a matter of solidarity. (Akhmouch \& Correia, 2016, p. 15)

\section{Woodhouse \& Muller (2017) state that}

Scales at which water flows, and is used, often cross political and administrative boundaries, economic agglomerations and social and cultural groupings; it impairs decisionmaking and poses significant challenges to governance. (Woodhouse \& Muller, 2017, p. 228).

Multi-level, federal and state institutional arrangements add more complexity to political processes and to the ability to make decisions (Newig \& Fritsch, 2009; Schulz et al., 2017).

Scale and level viability reflect water governance dimension, which structure must be flexible and adaptable in order to generate mutually acceptable policies that are collectively analysed and implementable (Daniell \& Kay, 2017).

Governance objectives are shared at multiple scales and different levels. The tendency is for traditional institutional structures to change to decentralize water governance across river basins, to align political and social boundaries with environmental ones, in search of collaborative opportunities and potential synergies (Kirchhoff et al., 2013; Lang et al., 2017; Nielsen et al., 2013). However, their practices transcend hydrological boundaries (Budds \& Hinojosa, 2012).

This reformulation in the state-society relationship tends to shift the scales and levels of decision making and transform the participation of those involved in decentralized and participatory governance (Freitas, 2015). For this, "governance networks" arise, since governance occurs in social and political networks (Sørensen \& Torfing, 2004). Empinotti et al. (2018) believe that the implementation of water governance practices goes beyond instrumental repairs (tools, rules and training). It shows the need for structural political changes.

As a result, new approaches are emerging that adjust traditional governance (stable and multifunctional systems with horizontally and mutually exclusive spatial and political domains) for adaptive governance with a more fluid system and juxtaposed jurisdictions. The concept of multi-level governance emerged from such aspects. This arrangement shows how institutions relate to each other at global, regional, national, state and local level in different (interdependent), although overlapping (nested), areas. This process lies on the inclusive, but non-exclusive, and decentralized participation of state and private actors in decisionmaking about the management of common pool resources (Earle \& Neal, 2017; Patrick et al., 2014).

Pahl-Wostl (2017) points out that

Current management practices are in the long-term neither economically, environmentally or socially sustainable since they only used financial and technical means to mitigate specific impacts rather than aiming at long-term sustainability. (Pahl-Wostl, 2017, p. 2923).

The author also defends governance as part of the social transformation required to maintain a better environmental state of river basins at multiple levels and scales. Thus, analysing how management practices, or in the case of this article, management instruments and institutions, are related to the achievement of good water governance can present the gaps to be overcome and the paths to be followed.

\section{OECD Water Governance Principles}

In 2015, the Organization for Economic Cooperation and Development (OECD) launched 12 Water Governance Principles (Table 1). These principles moored in legitimacy, transparency, accountability, human rights, state rights and inclusion aspects. Moreover, they aim to enhance water management systems in a sustainable, integrated and inclusive way. It must be done by updating such systems whenever necessary, at acceptable costs, within a reasonable period-of-time (Organization for Economic Co-operation and Development, 2015a, 2018).

Criticisms of the OECD Principles are also discussed. Taylor et al. (2019) discuss that the principles indicate that a signatory state assumes authority over water governance. Some aspects are privileged to the detriment of others, reinforcing extractive relations with water. For example, water conflicts are treated as an issue to be mostly resolved by the state.

Neto et al. (2018) stress the limitation of the application of the principles in transboundary rivers. Another problem is the invisibility of indigenous peoples, whether due to the absence or the scarcity of guidelines aimed specifically at these peoples. "The omissions suggest that Indigenous water justice is not considered a highlighted water governance" (Taylor et al., 2019, p. 10).

The second OECD water governance principle refers to 'manage water at the appropriate scale(s) within integrated basin governance systems to reflect local conditions and adopt coordination between different scales'. It seeks to promote multi-level cooperation among users, interested parts and governments in order to reinforce cooperation actions in shared river basins. This principle also encourages the integration of sub-basins to shared river basins (Organization for Economic Co-operation and Development, 2015a, 2018). The Brazilian water policy and its implementation are analysed in this research based on OECD Water Governance Principle 2. The São Francisco River Basin is the case study. 
Table 1. OECD Principles on Water Governance.

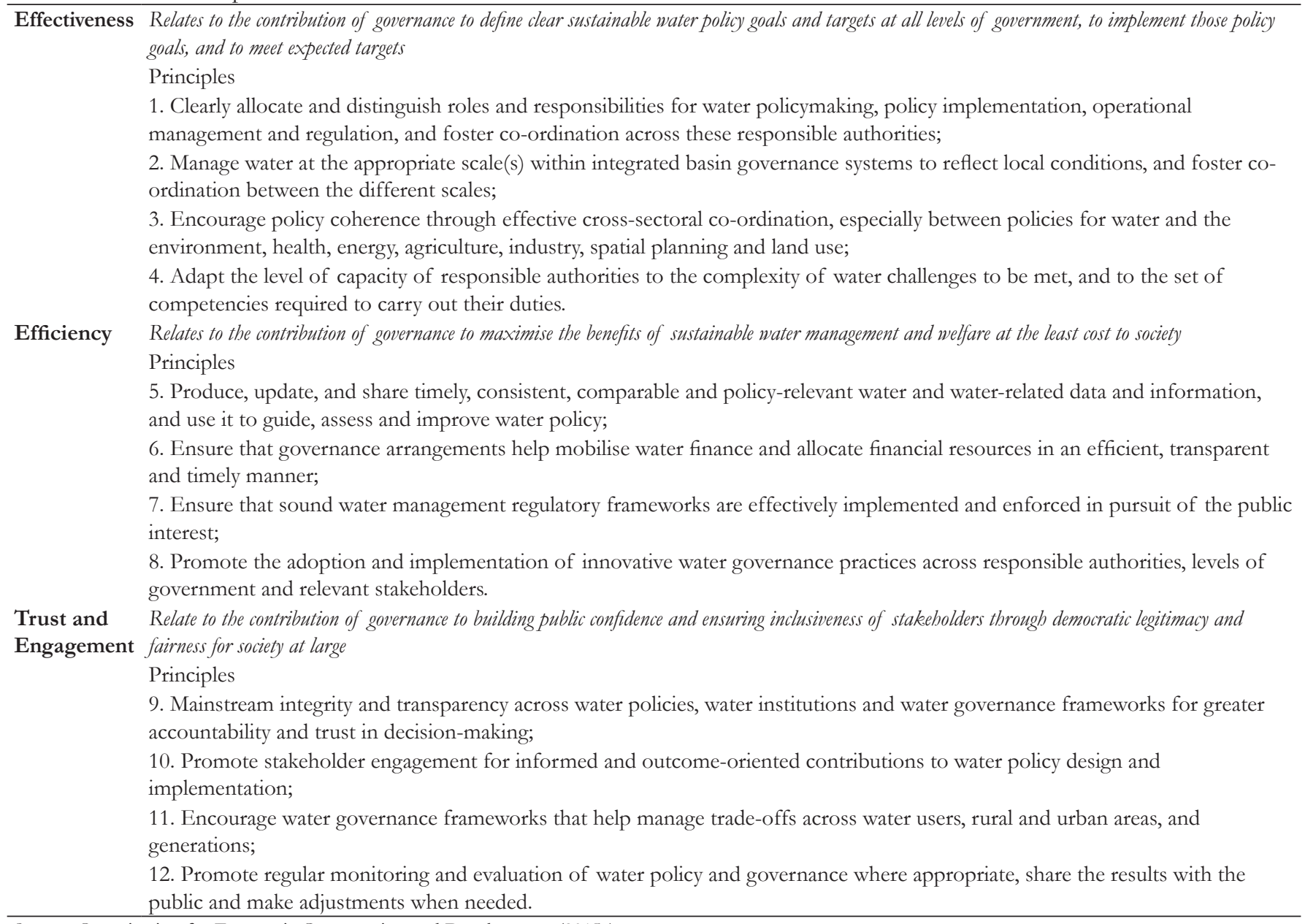

Source: Organization for Economic Co-operation and Development (2015a).

\section{BRAZILIAN WATER RESOURCES POLICY}

The Brazilian Water Resources Management System (SINGREH - Sistema Nacional de Gerenciamento de Recursos Hídricos) is ruled by Law 9.433/1997, which created the National Water Resources Policy (PNRH) and established six principles: a) water is a public asset; b) water is a limited natural resource with economic value; c) under water shortage, humans and animals have the priority for its use; d) water management must promote multiple water uses; e) the river basin is the territorial unit for implementing the PNRH; f) water resource management should be decentralized and involve government, users and civil society participation (Brasil, 1997).

Rivers have two domains in Brazil, namely: federal domain when they are shared by more than one state in the federation; and state domain when the river only flows within the territory of one state. Federal rivers can have sub-basins composed of stateowned rivers when the sub-basin stays in a single state. Water in reservoirs built by the federal government belongs to the federal domain, even if it regards a river under state domain.

The PNRH follows three planning levels: national, state and river basin. Five management instruments were established (Agência Nacional de Águas, 2017; Brasil, 1997):
- Water Resource Plans: Master plans organized to provide guidelines for the implementation of Brazilian water policy and water resource management activities. Plans are elaborated at three levels: national, state and river basins.

- Water Permits: Water use licences for rivers under federal domains are issued by the National Water Agency (ANA) and by the state agencies for rivers under state domain.

- Bulk Water charge: fee paid by users with access to water permits. It is not considered a tax, but a public charge, which is negotiated and defined based on public discussions conducted in the river basin committees. The incomes shall be used based on the river basin plan.

- Water body classification system based on the quality of the water: It consists of categorizing water bodies in water quality classes. Each class guides water uses based on the quality of the water observed in the water body.

- Water Resource Information System: it collects, stores and makes available quantitative and qualitative information about water resources, as well as about other factors influencing the water management system.

The PNRH defines management guidelines, aims and instruments and the SINGREH launch institutions to manage 
water resources (Siegmund-Schultze et al., 2015). The system is composed of deliberative and participatory agencies (water councils and basin committees), as well as of water management agencies responsible for policy implementation (Ribeiro, 2017b).

The SINGREH' hierarchy includes National and State Water Resources Councils, Ministry of Regional Development which accounts for ANA since January 2019, Basin Committees and basin agencies - technical agencies to support the river basin committees. It also includes other organs which competencies are related to water resources management (Agência Nacional de Águas, 2017; Brasil, 1997).

River Basin Committees are entities at the river basin level. They are consultative, normative and deliberative entities composed by civil society, water users and government representatives. Committees have multiple attributions towards the river basin they account for, as well as towards sub-basins tributary of the main watercourses and the tributaries of the referred tributary; or, yet, towards a set of contiguous river basins or sub-basins. They are in charge of approving and following the execution of water resource plans and of establishing the guidelines for water charge at the basin level. Water conflict mediations take place in the basin committee, at first (Brasil, 1997). However, most committees in place nowadays do not have financial sustainability due to lack of water charge systems. Such impairment can reinforce the lack of political support and of training for their members on how to put actions in practice (Morais et al., 2018).

\section{CASE STUDY}

The São Francisco River Basin (SFRB) crosses seven federation units in Brazil. It is an important interstate river basin under Federal Domain (Figure 2).

The river basin has $639,219 \mathrm{~km}^{2}$ of drainage area, which covers $8 \%$ of the total area of the country. Approximately $60 \%$ of its area is inserted in the semiarid region where most tributaries are intermittent, rainfall is irregular and evaporation rates are high (Bezerra et al., 2018; Comitê da Bacia Hidrográfica do Rio São Francisco, 2016).

The SFRB is divided into four physiographic regions, namely: Upper SFRB, Middle SFRB, Sub-Middle SFRB and Lower SFRB. They follow the river flow, which covers 34 sub-basins. It is possible identifying areas that present higher richness and areas of extreme poverty, as well as areas that present high and low demographic density (Comitê da Bacia Hidrográfica do Rio São Francisco, 2016).

The administrative scale includes the supranational, national, state and local levels. The SFRB is inserted territorially at the local level. In this research, the SFRB governance is studied both at a local macro level (the river basin as a whole) and at a micro level (the sub-basins).

The São Francisco River Basin Committee was launched in 2001, and it has a strong influence on matters concerning the river basin since then. Its rules and procedures have been updated
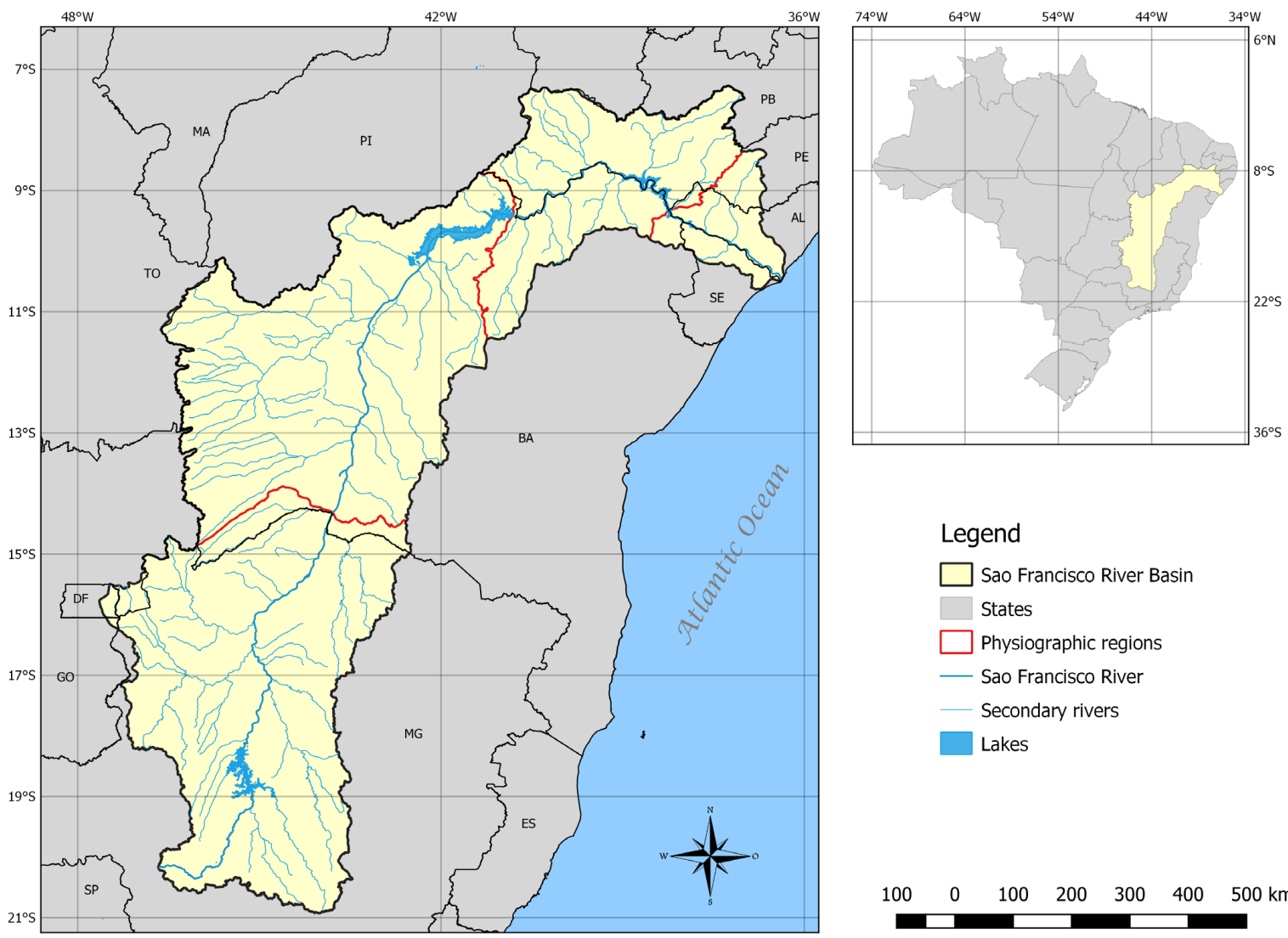

\section{Legend}

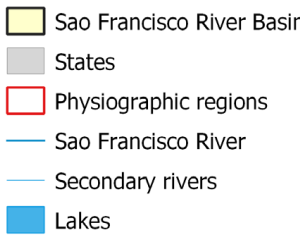

Figure 2. São Francisco River Basin and its location in Brazil.

Source: Elaborated by the authors. Based on data from GeoNetwork ANA. 
for 18 years and technical chambers have been created to evaluate different subjects that resulted in actions such as the elaboration of the 2004 River Basin Plan, which was updated in 2016. The bulk water charge system was put in practice in 2010 and was updated in 2017 (Agência Nacional de Águas, 2017; Assis \& Ribeiro, 2018).

Despite the several advances of the water management in the SFRB, it is possible finding impairments to relationships set at macro and micro levels - between the SFRB and the 34 sub-basins composing it. Most actions are taken in the main river canal. There is no detailed information about the sub-basins in the new Plan of the River Basin. The bulk water charge system reaches users who capture water from federal water bodies that are submitted to the São Francisco River Basin Committee (CBHSF). Therefore, there are no universal water charges for the river basin as a whole (Comitê da Bacia Hidrográfica do Rio São Francisco, 2016).

\section{METHODOLOGY}

The OECD developed the Water Governance Indicator Framework to help to assess its Water Governance Principles. The framework is composed of Traffic Light systems that encompass 36 indicators (three for each principle) and a checklist with 106 items about governance, which are listed in a short and mid-term action plan (Organization for Economic Co-operation and Development, 2018).

The Traffic Light baseline classifies indicators based on a six-colour scale that goes from 'In place, functioning', 'In place, partly implemented', 'In place, not implemented', 'Framing under development', to 'Not in place' and 'Non-applicable'. Each class refers to the current status of the analysed criteria (Organization for Economic Co-operation and Development, 2018).

Principle 2 of OECD concerns an appropriate scale(s), which was assessed in the present study. This Principle regards three indicators: 2.a - What? - Existence and implementation degree of integrated water resource management policies and strategies; $2 . \mathrm{b}-$ Who? - Existence and functioning of institutions managing water at river basin scale; 2.c - How? - Existence and implementation degree of cooperation mechanisms applied to water resources management across water-related users and levels of government from local to basin, regional, national and upper scale (Organization for Economic Co-operation and Development, 2018).

In this paper, Principle 2 indicators are analysed using two different methodologies. For the indicators 2.a and 2.b, it was adapted the Traffic Light suggested by the OECD in order to verify the degree of implementation of the PNRH. For this, data concerning implementation of management instruments is used. The qualitative analysis is considered for analysing the effectiveness of this implementation in improving good governance of water in river basins. For the third indicator - 2.c - it was preferred to examine the interaction networks between some scales with prominence in the Brazilian water scenario and between the different levels that make up each scale. The details of both methodologies are described in the following topics.

It was preferred to examine the interaction networks between some scales with prominence in the Brazilian water scenario and between the different levels that make up each one of them. The details of both methodologies are described in the following topics.

\section{Evaluation of Indicators 2.a and 2.b}

The first indicator (2.a) is evaluated in this paper through management instruments recommended by the Brazilian Water Policy: water resource plans, system to classify water bodies based on their water quality, water permits, bulk water charges and water resource information system. Some authors suggest that Brazilian water policy implementation could be measured by the implementation of its management instruments (Barbosa et al., 2017; Libanio, 2018).

The analysis of the indicator (2.b.) took into account the implementation and actions of river basin committees. These committees have great relevance as decision-making space to overlap local and state management limits; they promote regional integration, as highlighted by Sousa Júnior et al. (2016). The other institutions linked to multi-level water governance are ANA and National Water Resources Council (CNRH). They are analysed through the inter-scale and multi-level interrelationships. The SINGREH itself is a multi-level decision-making institutional system and its entities (as river basin committees, water resources councils and water agencies) must act considering multi-level relationships.

The Traffic Light scale by Organization for Economic Co-operation and Development (2018) was applied to these two indicators in order to assess the degree of implementation of Brazilian water resources policy instruments and the actions taken by river basin committees in sub-basins of São Francisco Basin. Six criteria were analysed: river basin committees, water resource plans, water permits, bulk water charges, water resources information system (or any type of online platform to outspread information on water resources) and systems to classify water bodies according to the quality of their water.

Adaptations in the Traffic Light scale included 'nonapplicable' class removal since all the selected criteria were applied to the analysis. The other classes were adapted, so that the higher the degree of a certain criterion, the better the current condition of these indicators. Class 'In place, functioning' was replaced by 'Very High'; 'In place, partly implemented' by 'High'; 'In place, not implemented' by 'Median'; 'Framing under development' by 'Low' and 'Not in place' by 'Very Low'. Scale colours were maintained, and they can be observed in Figure 3.

The study by Brito et al. (2020), official documents, the legislation, water resource plans and information systems were the main sources for the evaluation of indicators 2.a and 2.b. The scale and description of implementation degrees are shown in Table 2.

Information was added to spatial data - shapefiles made available by the National Water Agency - after the scale was determined to generate maps of the implementation degree of management instruments and the actions taken by river basin committees in each sub-basin in the entire São Francisco River Basin.

Result analysis was used to infer water governance evolution concepts based on Principle 2 of OECD. Possible gaps in BHSF's multi-level and inter-scale relationships were identified. 
Table 2. Degree of water management implementation based on instruments and river basin committee.

\begin{tabular}{|c|c|c|}
\hline & Degrees & Description \\
\hline \multirow{5}{*}{ 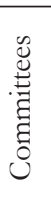 } & Very High & Installed committees - intense actions \\
\hline & High & Installed committees - but only a few actions put in place \\
\hline & Median & Recently installed committees and little actions are taken \\
\hline & Low & Committees under installation process \\
\hline & Very Low & No action was taken to install the committee in the river basin \\
\hline \multirow{5}{*}{ 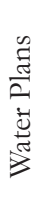 } & Very High & Plans having their planning horizons reached and updated \\
\hline & High & Plans remain in their planning horizons \\
\hline & Median & Plans having their planning horizons reached without updates \\
\hline & Low & Plan elaboration proposition in course \\
\hline & Very Low & No action was taken to elaborate the plan in the river basin \\
\hline \multirow{5}{*}{ 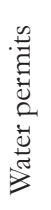 } & Very High & Implemented water permits and high supervision \\
\hline & High & Implemented water permits and partial supervision \\
\hline & Median & Implemented water permits and little or no supervision \\
\hline & Low & Water permits proposition by the legislation; its implementation is in course \\
\hline & Very Low & No action was taken to implement the water permits system in the river basin \\
\hline \multirow{6}{*}{ 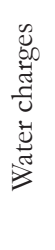 } & Very High & Stabilized water charges with updates / defaults lower than $10 \%$ \\
\hline & High & Water charges at adaptation stage / stabilized, without updates / defaults higher than $10 \%$ \\
\hline & Median & Recently implemented water charges and collection lower than $50 \%$ \\
\hline & Low & Water charges under the implementation process \\
\hline & Very Low & No action to implement the water charges system in the river basin \\
\hline & Very High & Monitoring and outspreading updated information \\
\hline \multirow{4}{*}{$\mathscr{a}$} & High & Monitoring and outspreading information that is not often updated \\
\hline & Median & The system/platform is in place, but it only has little information \\
\hline & Low & The proposition to create an information system / implementation phase \\
\hline & Very Low & The quali-quantivative situation of water resources are not monitored \\
\hline \multirow{5}{*}{ Un } & Very High & Existing SC with planning horizon reached and updated \\
\hline & High & Existing SC still in the planning horizon \\
\hline & Median & Existing SC with reached planning horizon, without updated \\
\hline & Low & SC proposition elaboration (discussion) in course \\
\hline & Very Low & No action was taken to elaborate a SC proposition \\
\hline
\end{tabular}

$\mathrm{SC}=$ System of classification; IS = Information System

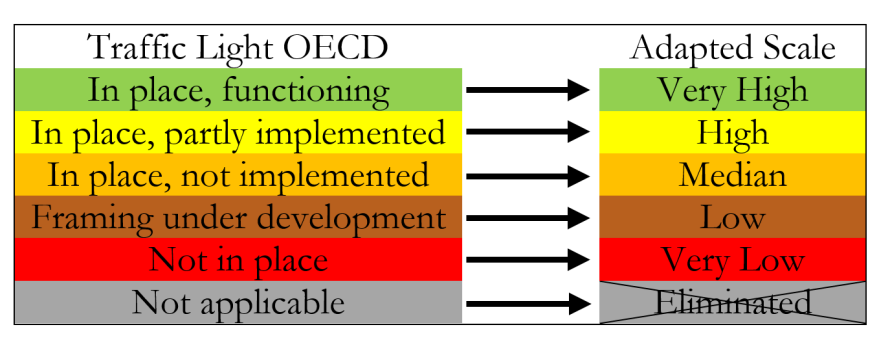

Figure 3. Adaptations in the Traffic Light Scale. Source: Elaborated by the authors.

\section{Evaluation of Indicator 2.c}

Indicator 2.c is verified based on the multi-level and interscale interaction of selected criteria to point out cooperation mechanisms. The multi-level and inter-scale interaction network developed by Daniell \& Barreteau (2014) was chosen to assess these interactions. Three scales and their corresponding levels were selected from Daniell \& Barreteau (2014) to build the interaction network, whose existing interactions could be designed, according to the model shown in Figure 4.

The local level was divided into two sub-levels - macro local (river basin) and micro local (sub-basins) - to highlight the multi-level interaction in Brazilian river basins. Two networks were created for each criterion: i) featuring interactions between scales and ii) considering levels on the same scale.

\section{RESULTS AND DISCUSSION}

Table 3 synthesizes the implementation degree of management instruments and the performance of river basin committees in the SFRB sub-basins, regarding the frequency of meetings and the number of actions taken. Throughout the discussion of the results of this table, qualitative analyses have been performed.

The implementation of these criteria in some sub-basins such as in Rio das Velhas Basin and Verde Grande River Basin was classified as High and Very High. On the other hand, in some river basins, mainly in the smaller ones (located in the SubMiddle SFRB and Lower SFRB regions), the water management implementation degree is very low. None of the river basins in the Lower SFRB region was classified at Very High Implementation Degree. The worst situation was observed in the Seco/Talhada River Basin and Rio de Janeiro/Formoso River Basin. These last two river basins are in smaller sub-basins that do not present significant water availability to the river basin.

Minas Gerais State stands out in the implementation of the PNRH since it holds the sub-basins recording the best implementation degrees. Bahia State shows significant improvement 

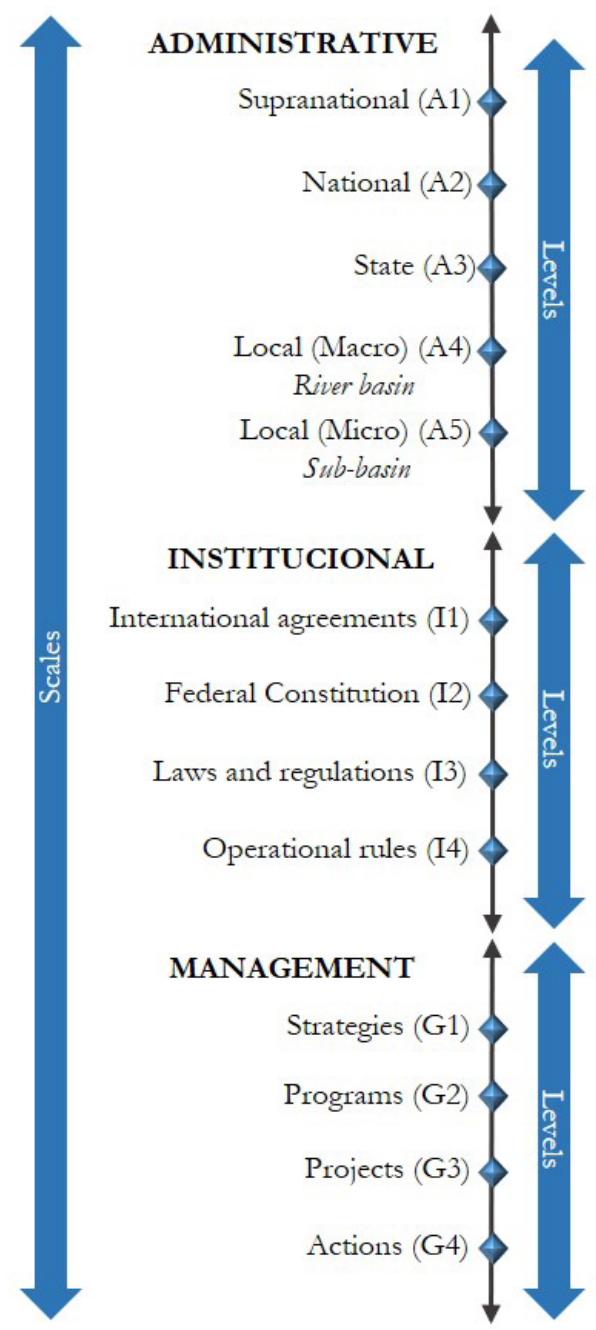

Figure 4. Scales and levels of the interaction network applied to analyse Indicator 2.c. of OECD Water Governance Principles. Source: Elaborated by the authors. Based on Daniell \& Barreteau's (2014) methodology.

in the last few years. The water resource plans of the river basin developed in this state were updated and have been enhanced. The river basin committees in Bahia State have their actions improved due to frequent meetings to discuss relevant issues, including the mediation of water conflicts. Sub-basins located in Alagoas and Sergipe (in the Lower SFRB region) are those facing the worst implementation degrees.

Sub-basins with an installed and operational committee were classified as High and Very High and presented better results in the other criteria. This association highlights the connection between Indicators $2 \mathrm{a}$ and $2 \mathrm{~b}$ (existence and functioning of water management institutions, and the existence and implementation degree of integrated water resources management policies and strategies). Therefore, there is more compliance with Principle 2 and it means better water management at local sub-basin level.

This result corroborates the statements by Sousa Júnior et al. (2016) when they say that committees can promote regional integration and act as the most important decision-making space to leverage water policy in a watershed. Integration between river basin and sub-basin is stronger in these cases, as well as the multi- level association between the BHSF and the Salitre River Sub-basin, which was studied by Brito et al. (2020). It is expected to observe the overlap of affluent committee members composing CBHSF. It is essential to improve the power-sharing ability at different levels. This process characterizes major disadvantages in basins that are not represented due to a lack of local committee.

However, even for committees implemented and active, the lack of strengthening of the problem-solving capacity reduces its performance in management actions. An example of this can be seen in the difficulty of resolving conflicts in the Salitre River Basin. This sub-basin faces long unresolved conflicts: the intensification of the use of water for irrigation, due to the Salitre Irrigation Project; and, the decrease of the flow in the course (Comitê da Bacia Hidrográfica do Rio Salitre, 2017). Rossi \& Santos (2018) reflect that

Decisions about the use of water challenge established and consolidated knowledge and technical procedures and, in many circumstances, obscure causal relationships and legitimize interventions and hegemonic interests. (Rossi \& Santos 2018, p.164, our translation).

The existence of an updated basin plan is another important aspect of developing sub-basin water policy implementation. The best-rated basins, based on this criterion, also presented the best results in the other criteria, except for water use charges. The hard time implementing these charges is evident in many low ratings.

Results recorded for each criterion were spatialized and are shown in the maps presented in Figure 5. The implementation level classification was based on actions taken by river basin committees (Map 1 - Figure 5) have shown that only three of these basins presented 'Very High' implementation and action degrees: Pará, Rio das Velhas and Verde Grande basins. Committees in these areas take more intense actions in PNRH execution, and such intensity reflects the high degree of management-instrument implementation. These sub-basins have already implemented the bulk water charge, their plans were already elaborated and updated, and they have larger amounts of information available.

Of the 34 sub-basins, only 18 have committees installed. The Upper and Middle SFRB regions recorded the best results. On the other hand, the Sub-Middle and Lower SFRB regions still demand policies and actions to create the committees. Therefore, most of their river basins were classified as 'Very Low' and 'Low'. Freitas (2015) identified the same situation in the SFRB; he stated that the greatest difficulty in this shared river basin lies on integrating the efforts of all committees into collective actions.

However, since 2017, 18 federative units joined the PROCOMITES - National Program for the Strengthening of River Basin Committees, which should stimulate the discussion for the design of the non-existent basin committees. In the SFRB, only Minas Gerais did not adhere to the program (Agência Nacional de Águas, 2020).

By taking into consideration implementation of the criterion 'water resource plans' (Map 2 - Figure 5), one can observe higher variability in the implementation degrees, going from 'Very High' to 'Very Low'. All states have their own plan. The oldest plans 
Table 3. Water management implementation degrees at the SFRB sub-basins.

\begin{tabular}{|c|c|c|c|c|c|c|c|c|}
\hline & Sub-basin & Domain & Committee & Plans & $\begin{array}{c}\text { Water } \\
\text { permits }\end{array}$ & $\begin{array}{c}\text { Water } \\
\text { charges }\end{array}$ & SC & IS \\
\hline \multirow{14}{*}{ 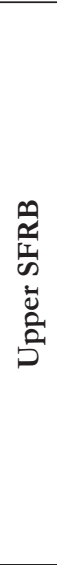 } & Afluentes Mineiros Alto SF & MG & High & High & High & Low & Low & Median \\
\hline & Para & MG & Very High & Median & High & High & Low & Median \\
\hline & Paraopeba & MG & High & High & High & Low & Low & Median \\
\hline & Entorno Três Marias & MG & High & High & High & Low & Low & Median \\
\hline & Velhas & MG & Very High & Very High & High & High & Very High & High \\
\hline & Paracatu & $\mathrm{MG} / \mathrm{DF} / \mathrm{GO}^{*}$ & Low & Median & High & Low & Median & Median \\
\hline & Rio de Janeiro/Formoso & MG & Very Low & Very low & High & Low & Very Low & Median \\
\hline & Jequitai & MG & High & High & High & Low & Median & Median \\
\hline & Alto Preto & $\mathrm{MG} / \mathrm{DF} / \mathrm{GO}^{*}$ & Low & High & High & High & Low & Median \\
\hline & Urucuia & MG & High & High & High & Low & Low & Median \\
\hline & Pacui & MG & High & High & High & Low & High & Median \\
\hline & Verde Grande & $\mathrm{MG} / \mathrm{BA}^{*}$ & Very High & High & High & High & High & Very High \\
\hline & Pandeiros/Pardo/Manga & MG & High & High & High & Low & Low & Median \\
\hline & Carinhanha & $\mathrm{MG} / \mathrm{BA}^{*}$ & Very Low & High & High & Low & Low & Median \\
\hline \multirow{6}{*}{ 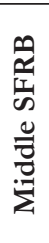 } & Corrente & $\mathrm{BA}$ & High & Median & High & Low & Low & Median \\
\hline & Paramirim/St Onofre & $\mathrm{BA}$ & High & High & High & Low & High & Median \\
\hline & Alto Grande & BA & High & Median & High & Low & Low & Median \\
\hline & Medio/Baixo Grande & $\mathrm{BA}$ & High & Median & High & Low & Low & Median \\
\hline & Banks of Sobradinho Lake & $\mathrm{BA}$ & High & Very Low & High & Low & Very Low & Median \\
\hline & Verde/Jacare & $\mathrm{BA}$ & High & Very High & High & Low & High & Median \\
\hline \multirow{9}{*}{ 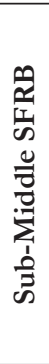 } & Rio do Pontal & $\mathrm{PE}$ & Low & Median & Median & Low & Very Low & Median \\
\hline & Salitre & BA & High & Very High & High & Low & High & Median \\
\hline & Garças/GI6/GI7 & PE & Low & Median & Median & Low & Very Low & Median \\
\hline & Curaça & $\mathrm{BA}$ & Very Low & Median & High & Low & Very Low & Median \\
\hline & Brigida & $\mathrm{PE}$ & Low & Median & Median & Low & Very Low & Median \\
\hline & Terra Nova/GI4/GI5 & PE & Low & Median & Median & Low & Very Low & Median \\
\hline & Macurure & BA & Very Low & Median & High & Low & Very Low & Median \\
\hline & Pajeu/GI3 & PE & Very Low & Median & Median & Low & Very Low & Median \\
\hline & Moxoto & $\mathrm{PE} / \mathrm{AL}^{*}$ & Low & Median & High & Low & Low & Median \\
\hline \multirow{5}{*}{ 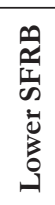 } & Seco/Talhada & $\mathrm{AL}$ & Very Low & Very Low & High & Low & Very Low & Median \\
\hline & Curituba & SE & Low & Very Low & Median & Low & Very Low & High \\
\hline & Alto Ipanema & $\mathrm{PE} / \mathrm{AL}^{*}$ & Low & Very Low & High & Low & Low & Median \\
\hline & Bx. Ipanema/Bx. SF (AL) & $\mathrm{PE} / \mathrm{AL}^{*}$ & Low & Very Low & High & Low & Low & Median \\
\hline & Baixo SF (SE) & SE & Very Low & Very Low & Median & Low & Low & High \\
\hline
\end{tabular}

*Federal Government Domain; SC = System of classification; IS = Information System

are the ones elaborated in Pernambuco (1998) and Bahia (2004) states. The other states published their plans after 2010.

The best river basin-plan conditions were observed in three sub-basins: Rio das Velhas, Verde-Jacare, and Salitre, whose resource plans and actions already reached their recent targets; therefore, they achieved 'Very High' implementation degree.

However, many sub-basins do not have a water resource plan yet. In the region of Baixo SF, there is no action to prepare plans in any of the sub-basins. This situation was also identified in the sub-basins Rio de Janeiro / Formoso and Margem Esquerda do Lago de Sobradinho, which led to the classification in a "Very Low" degree. The other sub-basins have a published plan, some still in the planning horizon (classified as "High"), others out of date (classified as "Medium").

Furthermore, there is not enough condition for execution of several plans that have been drawn up. Organization for Economic Co-operation and Development (2015b) highlights that the lack of financing and the limited capacity to execute planned actions are the main aspects that point to poor coordination of water resources plans. Therefore, the elaboration of this document, by itself, is not capable of making water resources planning efficient.

An example of the inability to carry out the actions of a water resources plan can be analysed in the Salitre River Basin. Its plan was published in 2017 and one of its programs - Strengthening of the Governance Network - foresees seven actions for its execution, all with a start scheduled for the first and second year of the document's planning horizon. However, currently in 2020 there is no action initiated or even discussed within the committee. The committee has drafted only one resolution and three meeting minutes are available for public consultation. None of them with themes about the program mentioned above (Comitê da Bacia Hidrográfica do Rio Salitre, 2017; Instituto do Meio Ambiente e Recursos Hídricos, 2020).

Water permits embodied aspects related to water resource enforcement (Map 3 - Figure 5). All sub-basins presented implementation degree between 'High' and 'Median'. By analysing 


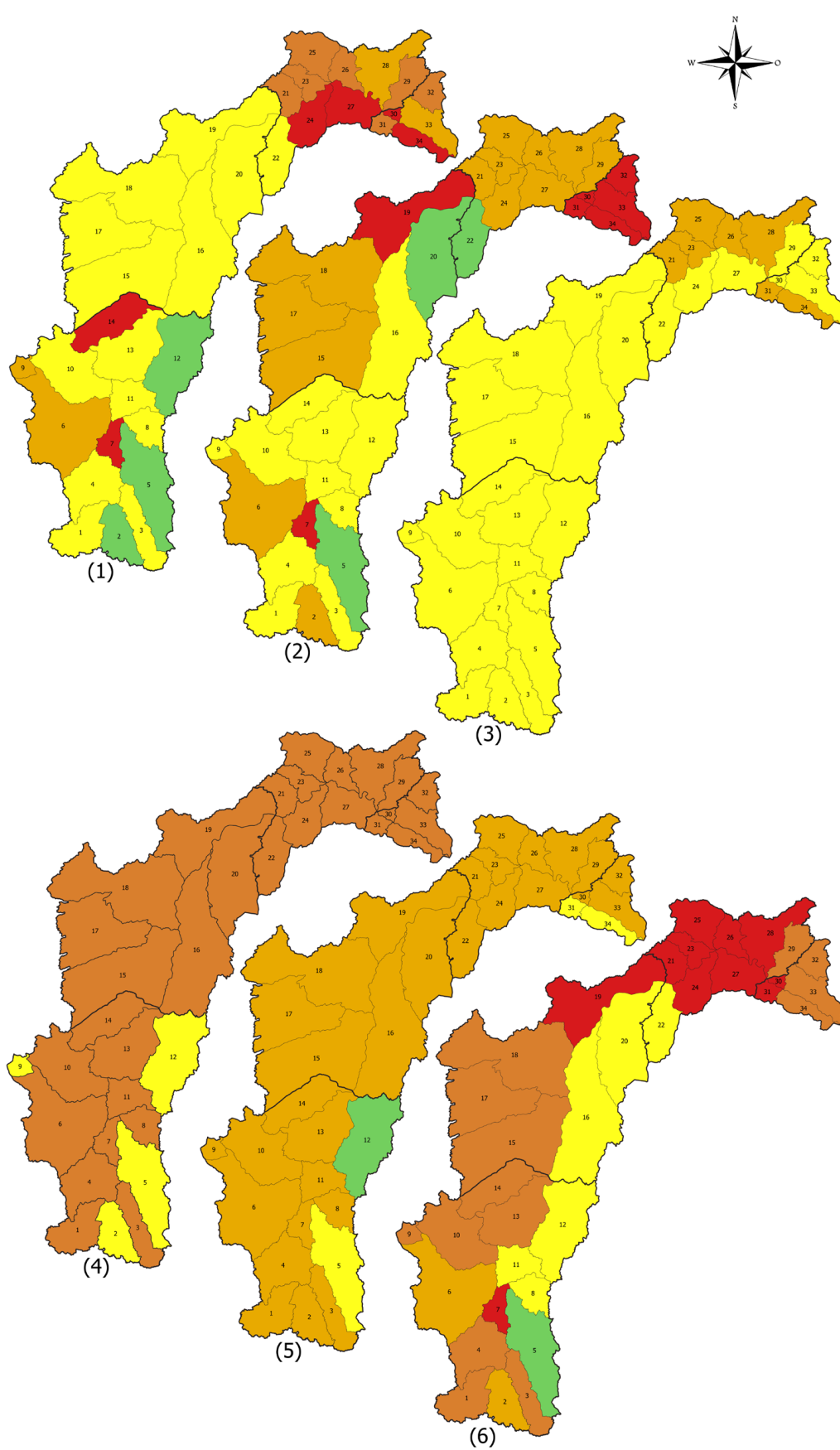

Sub-basin

1. Afluentes Mineiros do Alto SF

2. Pará

3. Paraopeba

4. Entorno Represa Três Marias

5. Velhas

6. Paracatu

7. Rio de Janeiro/Formoso

8. Jequitaí

9. Alto Preto

10. Urucuia

11. Pacuí

12. Verde Grande

13. Pandeiros/Pardo/Mangai

14. Carinhanha

15. Corrente

16. Parnamirim/St Onofre/Canaíb

17. Alto Grande

18. Médio/Baixo Grande

19. Margem Lago Sobradinho

20. Verde/Jacaré

21. Rio do Pontal

22. Salitre

23. Garças/GI6/GI7

24. Curaça

25. Brígida

26. Terra Nova/GI4/GI5

27. Macururé

28. Pajeú/GI3

29. Moxotó

30. Seco

31. Curituba

32. Alto Ipanema

33. Bx Ipanema/Bx SF(AL)/Piauí

34. Baixo São Francisco (SE)

Degree of implementation

$\square$ Very High

$\square$ High

$\square$ Median

Low

Very Low

Criteria

(1) River Basin Committees

(2) Water Resource Plan

(3) Water rights

(4) Bulk water charges

(5) Information System

(6) System for classification

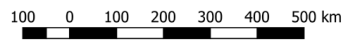

Figure 5. Water management implementation degrees in the SFRB sub-basins (maps).

Source: Elaborated by the authors, based on data from GeoNetwork ANA.

water permits alone, one can see that all river basins had wellestablished water permits criteria and a system focused on the concession of use rights. However, the situation in some states is unfavourable if one takes into account the absence of monitoring and enforcement.

Based on the analysis of the platforms for the dissemination of state information or websites, the Bahia State makes many oversights and inspection actions available, but they have not been updated since 2009. There is no information about enforcement actions in Pernambuco, Alagoas and Sergipe states, and it highlights the lack of these types of action; therefore, their river basins were classified at 'Median'.

The lack of an efficient inspection causes problems and conflicts for the use of the water even in river basins with an effective water permits. Ribeiro et al. (2018) highlight one of the problems of the Rio das Velhas Basin. In 2013, the river basin committee identified that $80 \%$ of water availability is granted in some stretches of the river, without considering the insignificant uses. Only in 2015, the Committee created a flow management group, but which did not issue a final report on its activities. In 2017, the Committee started the process of re-registering water 
users. The authors also point out "The State's impossibility to grant the right to use water resources demanding users" (Ribeiro et al., 2018, p. 350, our translation).

When it comes to bulk water charges (Map 4 - Figure 5), although the situation is uniform, it remains unfavourable. Only 3 of the 34 sub-basins have fully implemented this instrument. The water charge system established to Pará and Verde Grande sub-basins was recently launched (in 2017) and it remains at adjustment stage. Rio das Velhas sub-basin charges water resource use since 2010, but the system was not updated yet. Alto Preto sub-basin (Minas Gerais State) charges water use since 2014, but without updates. So, all these river basins were classified as 'High' implementation degree.

Other sub-basins (located in Pernambuco, Alagoas, Sergipe and Bahia states) are at different implementation degrees. Pernambuco State is preparing a study about water charge system implementation, which is about to be approved. Alagoas State started discussions about a possible water charge system implementation in its river basins. Sergipe State started studies about launching a water charge system, but it did not include the SFRB sub-basins. Since 2006, Bahia State has been charging sanitation users for bulk water supply through a system similar to that of the SFRB.

The lack of an universal bulk water charge for all users can lead to conflicts over water use. Some users started to abstract water in the tributary rivers where the charge had not been implemented. This has resulted in conflicts between users of the main river and of sub-basins due to reduced water availability (Assis et al., 2018; Vera et al., 2017).

All states in the SFRB have an information system or some sort of online platform to outspread information. Because most of them do not have a large amount of information or have information that is not updated so often, the sub-basins located in these states were classified as 'Median' implementation degree when it comes to water resources information system (Map 5 Figure 5). The only exceptions were the river basins in Sergipe State, which have recently improved the information dissemination about their water resources. Rio das Velhas and Verde Grande subbasins also make lots of information available in the platforms of river basin committees. Such information availability allowed their classification as 'High' and 'Very High' implementation degree.

The System for water quality classification (Map 6 - Figure 5) was the only one amongst the management instruments that presented five implementation-level classes. Most sub-basins have been classified as 'Low' or 'Very Low' implementation degree, mainly the ones composing the Sub-Middle SFRB and Lower SFRB regions. Only Rio das Velhas Sub-basin was classified as 'Very High' implementation degree since it was the only one that had recently updated its 'System for classification' process.

However, problems are identified even in river basins with the system for water quality classification elaborated. Machado et al. (2019) point out problems in the elaboration of diagnoses and in the definition of parameters and scenarios. In addition, the authors highlight the absence of guidelines regarding the improvement in water quality.

Regarding Indicator 2.a., the existence and implementation level of policies and integrated water resource management strategies -management instruments applied at the micro local level of the SFRB (sub-basins) - showed that the implementation of the Brazilian water policies is not uniform. Some strategies are better implemented while some others remain incipient. This scenario points towards the hard time to implement integrated strategies focused on shared and large river basins, such as the SFRB.

As for Indicator 2.b. - existence and functioning of water management institutions at hydrographic scale -, the analysis of the river basin committee as a deliberative and participatory entity at micro local scale highlighted the importance of its creation to enhance the implementation of the herein addressed instruments. The longer the existence of the committees, the better the actions and enhancements in water governance. The existence and functioning of water management at the micro local scale also reflect the greater multi-level interaction with both the macro local (the basin) and state levels. Multi-level interaction stood out in sub-basins in states that present water-policy implementation ahead of schedule.

Water management in Brazil at different national, state and water basin levels are appropriate for water management scale based on Principle 2 in integrated systems. However, the analysis of indicators in the BHSF evidenced that system complexity is hindering this integration.

The complexity observed in a basin such as São Francisco due to its large area and domain heterogeneity, and water availability in its sub-basins makes its multi-level governance system even more challenging. According to Siegmund-Schultze et al. (2015), such system coexists with inevitable internal and external friction, but government agencies are not able to share roles and responsibilities yet.

The interaction network was created to verify multiscale and multi-level interactions between committees and Brazilian water policy management instruments in the SFRB (Figure 6).

The six criteria showed two interaction inter-scale and multi-level forms to the three assessed scales: administrative, institutional and management. The Supranational (A1) and International agreement (I1) levels were not evaluated since the SFRB is a national basin. These levels account for situations in international transboundary basins.

River basin committee interactions in the institutional scale at national (A2), state (A3), macro local (A4) and micro local (A5) level happen due to the proposition of laws and regulations (I3), and of operation rules (I4), at the four management levels. Moreover, the national level interacts with the institutional scale (Federal Constitution - I2) and with the developed strategies (G1), because of federal determinations and PNRH implementation by the government agencies, such as ANA. Such agencies are responsible for effectively applying the water law and for regulating, monitoring and planning action.

Plans, water permits, bulk water charges and classification systems have the same interaction networks as the committees. The national (A2), state (A3), macro local (A4) and micro local (A5) levels interact with the institutional scale through the proposition of laws and regulations, and of operational rules, at the four management levels. The administrative scale interacts with operational rules in the information system. This outcome is justified by the operation model of Brazilian information systems, which are in charge of outspreading information about water resource data. 


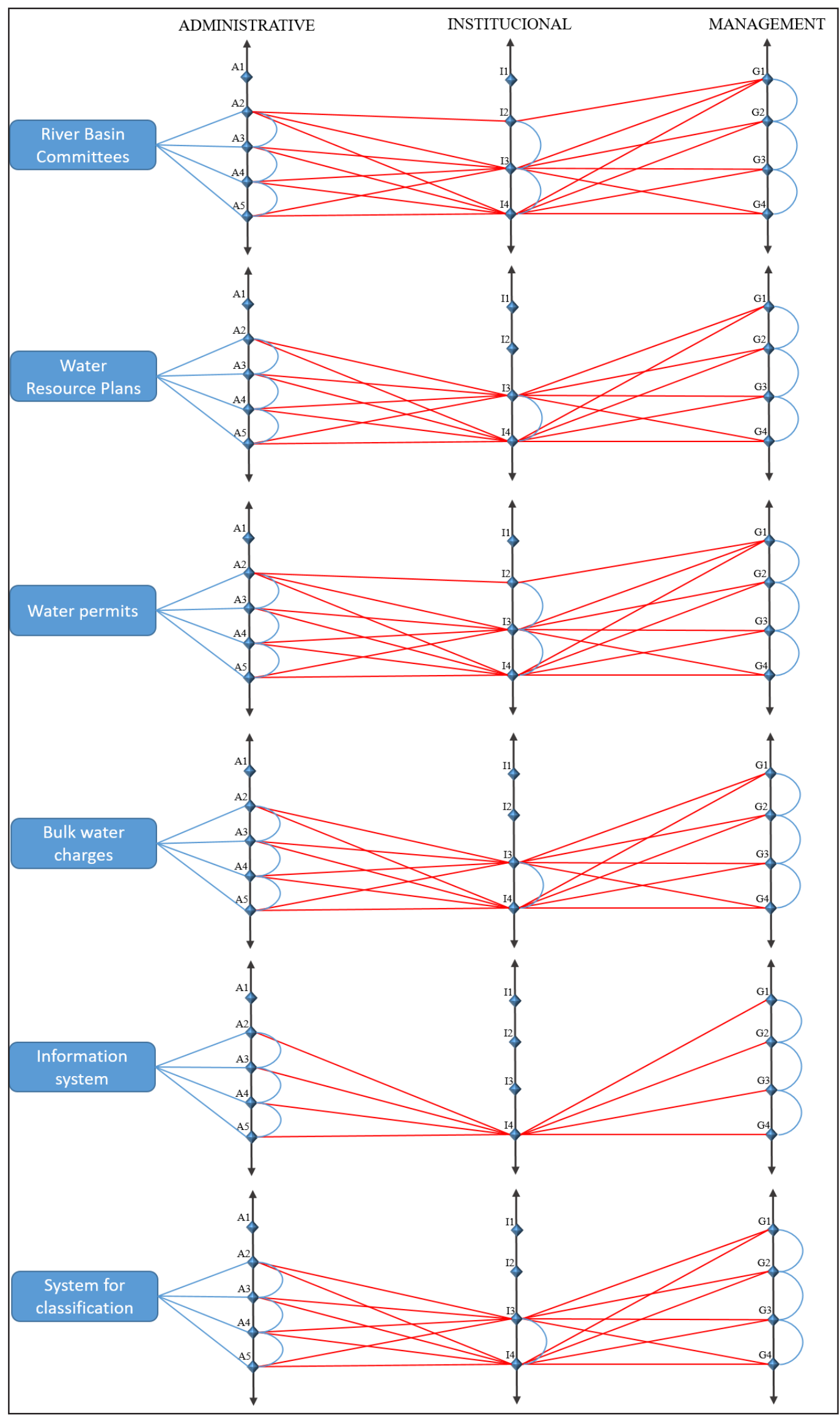

Figure 6. Interaction networks in the São Francisco River Basin considering administrative, institutional and management scales as defined by Daniell \& Barreteau (2014). 
Indicator 2.c. - existence and implementation level of cooperation mechanisms set for all users and levels of government and local, regional, national and higher river basin levels boosted the analysis of inter-scale and multi-level interaction networks as a cooperation tool, since the Brazilian water policy states that water management must be integrated, participative and decentralized. The interaction network highlights that the predicted and idealized interaction in the legislation can be perceived either in the committee or in management instruments based on conceptual terms.

However, by analysing the performance of practices, and by comparing results recorded for the network of interactions with implementation degree criteria results, one can see that interaction is not efficient, or uniform, since policies remain not fully implemented 23 years after their implementation in a relevant national river basin such as the SFRB.

\section{CONCLUSION}

Although the SFRB presents a high implementation degree of the PNRH management instruments at the macro level, as well as a highly active Basin River Committee, it also shows worrying aspects at the micro level. The 34 sub-basins which compose this river basin present great water management degree variability. Water permits instruments and river basin plans are the best implemented in the sub-basins. The worst scenario regards the bulk water charges instrument. The best results were recorded for sub-basins located in the Upper and Median SFRB regions when comparing to the Sub-Middle and Lower SFRB regions. Such a fact may be justified by the effort of Minas Gerais and Bahia states manage the water resources in the SFRB, given the great representativeness of their contribution areas $(85 \%$ of the total extension of the SFRB). Moreover, areas inserted in the semiarid region, the ones belonging to the Brazilian Northeast (Sub-median and Lower SFRB regions) have lower water availability.

However, the state of Bahia, despite good progress in the implementation of the instruments, faces problems in water management due to difficulties in resolving conflicts over the use of water.

The implementation of river basin committees is the first step towards the implementation of water management instruments and other actions of the PNRH. Although the SFRB Committee was created almost two decades ago, most sub-basin committees still need improvements, and some sub-basins do not even have a committee yet. Based on these results, sub-basins showing active committees have advanced management-instrument implementation processes. Although, many of them are not able to execute the instruments efficiently and need improvements to reach the governance objectives.

The interaction network (considering inter-scale and multi-level interactions) shows that some of these interactions are conceptual only. The expected interaction does not show good results in the São Francisco River Basin, given the multiple levels involved at management scale. If the expected interaction could be applied in a balanced way, the implementation of water policies would be uniform in all its sub-basins, in all involved states. The challenge lies on following all the established criteria over a shared and large basin as the SFRB. There is no way to better manage water in integrated systems without advancing at all levels.

Managing water resources at appropriate scales and levels in a basin that encompasses a federal, state and river basin and its 34 sub-basins is a difficult task. The reasons for this can be both because of territoriality (border limitations and geopolitical barriers) and of governance aspects (overlapping legal and institutional layers and lack of congruence between decisionmaking spaces). Therefore, implementing water policies at all these spheres is the first step towards integrating and strengthening of the governance system.

Based on the results, one can see the importance of a broader articulation between sub-basins and management entities at different levels of administrative scale (federal, state and river basin) and at different scales (institutional and management). It would allow governance to be similar and balanced in the entire river basin. Siegmund-Schultze et al. (2015) also observed the difficulty in achieving multi-level governance. They have pointed out that the main challenge faced by entities involved in the SFRB water management lies on the articulation and associations in the institutional scenario at federal and state levels.

The implementation of policies and strategies, as well as the functioning of institutions and cooperation mechanisms, are basic indicators for Principle 2 of OECD (Appropriate scales within basin systems). In the case of the SFRB, some advances can be identified, but more effort is needed in order to achieve a better performance if one takes into consideration the basin as a whole. As it has already been observed by Gillet et al. (2014), the deficiency at the micro level, in such a significant river basin, can lead to setbacks and barriers to water governance in the assessed river basin at the macro level.

The application of these governance principle indicators was a first step towards evidencing the real situation faced by the $\mathrm{SFRB}$ in terms of integrated management between scales and levels. Just identifying the degrees of implementation of the basin committee and management instruments is not enough to analyse multi-level governance in basins at different levels. Qualitative analysis is necessary to complement the discussion.

The fact that the SFRB is such a complex basin is one of the reasons for not achieving full progress more than 20 years after the enactment of the PNRH. On the other hand, if this basin has such a significant advance at local macro-level (basin level), why would it not reflect on the sub-basins? The role of states in sub-basin management is stronger than the association between basin and sub-basin. There is a greater progress in managing river basins which are located in states with a better water policy management.

\section{ACKNOWLEDGEMENTS}

The first author receives a doctoral grant from the FAPESQPB/CAPES Foundation, Process No. 88887.142340/2017-00. The research is part of the project "Governança de Água: análise e avaliação em contexto de múltiplas escalas e dupla dominialidade" funded by CNPq (Process 421877/2018-9). The authors thank the support of all institutions. 


\section{REFERENCES}

Akhmouch, A. (2012). Water Governance in Latin America and the Caribbean: A Multi-Level Approach. Paris, France: OECD Publishing.

Akhmouch, A., \& Correia, F. N. (2016). The 12 OECD principles on water governance - When science meets policy. Utilities Policy, 43, 14-20. http://dx.doi.org/10.1016/j.jup.2016.06.004.

Agência Nacional de Águas - ANA. (2017). Brazilian Water Resources Report - 2017: FULL REPORT. Brasília: ANA.

Agência Nacional de Águas - ANA. (2020). Procomitês - Programa Nacional de Fortalecimento dos Comitês de Bacias Hidrográficas: Relatório de Acomplanhamento. Brasília: ANA. Retrieved in 2020, July 27, from https://www.ana.gov.br/programas-e-projetos/procomites

Assis, W. D., \& Ribeiro, M. M. R. (2018). A atualização do sistema de cobrança pelo uso da água da bacia hidrográfica do Rio São Francisco. Simpósio de Recursos Hidricos Do Nordeste, XIV, 2014, 1-10.

Assis, W. D., Ribeiro, M. M. R., \& Moraes, M. M. G. A. (2018). Proposal for improvements in the Raw Water Charge System of the São Francisco River Basin - Brazil. ESA, 23(4), 779-790.

Baranyai, G. (2019). Transboundary water governance in the European Union: The (unresolved) allocation question. Water Policy, 21(3), 496-513. http://dx.doi.org/10.2166/wp.2019.033.

Barbosa, M. C., Mushtaq, S., \& Alam, K. (2017). Integrated water resources management: are river basin committees in Brazil enabling effective stakeholder interaction? Environmental Science \& Policy, 76(October), 1-11. http://dx.doi.org/10.1016/j.envsci.2017.06.002.

Berg, S. V. (2016). Seven elements affecting governance and performance in the water sector. Utilities Policy, 43, 4-13. http:// dx.doi.org/10.1016/j.jup.2016.04.013.

Bezerra, B. G., Silva, L. L., Silva, C. M. S., \& Carvalho, G. G. (2018). Changes of precipitation extremes indices in São Francisco River Basin, Brazil from 1947 to 2012. Theoretical and Applied Climatology, 135, 1-12.

Brasil (1997, 09 de janeiro). Lei no 9.433, de 8 de janeiro de 1997. Institui a Política Nacional de Recursos Hídricos, cria o Sistema Nacional de Gerenciamento de Recursos Hídricos. Diário Oficial [da] República Federativa do Brasil, Brasília, seção 1, 470 p.

Brito, Y. M. A., Ribeiro, M. M. R., Silva, S. R., Medeiros, Y. D. P., \& Assis, W. D. (2020). Proposta metodológica para avaliar graus de implementação da Política Nacional de Recursos Hídricos em distintas escalas de planejamento. Revista DAE, 68(224):94-112.

Budds, J., \& Hinojosa, L. (2012). Restructuring and rescaling water governance in mining contexts: The co-production of waterscapes in Peru Jessica. Water Alternatives, 5(1), 119-137.

Cash, D. W., Adger, W., Berkes, F., Garden, P., Lebel, L., Olsson, P., Pritchard, L., \& Young, O. (2006). Scale and Cross-scale dynamics: governance and information in a multilevel world. Ecology and Society, 11(2), 8. http://dx.doi.org/10.5751/ES-01759-110208.

Comitê da Bacia Hidrográfica do Rio Salitre - CBHS. (2017). Plano de Recursos Hídricos da Bacia Hidrográfica do Rio Salitre: Síntese Executiva. Salvador: CBHS.

Comitê da Bacia Hidrográfica do Rio São Francisco - CBHSF. (2016). Plano de Recursos Hidricos da Bacia Hidrográfica do Rio São Francisco: Resumo Executivo. Maceió: CBHSF.

Daniell, K. A., \& Barreteau, O. (2014). Water governance across competing scales: coupling land and water management. Journal of Hydrology, 519, 2367-2380. http://dx.doi.org/10.1016/j. jhydrol.2014.10.055.

Daniell, K. A., \& Kay, A. (2017). Multi-level governance: an introduction. In K. A. Daniell \& A. Kay (Eds.), Multi-level Governance: Conceptual challenges and case studies from Australia (pp. 3-32). Australia: ANU Press.

Earle, A., \& Neal, M. J. (2017). Inclusive transboundary water governance. In E. Karar (Ed.), Freshwater Governance for the 21st Century (pp. 145-158). Cham, Switzerland: Springer International Publishing. http://dx.doi.org/10.1007/978-3-319-43350-9_8.

Empinotti, V. L., Gontijo Jr, W. C., \& Oliveira, V. E. (2018). Federalism, water, and (de)centralization in Brazil: The case of the São Francisco River water diversion. Regional Environmental Change, 18(6), 1655-1666. http://dx.doi.org/10.1007/s10113018-1371-1.

Freitas, C. (2015). Old Chico's new tricks: Neoliberalization and water sector reform in Brazil's Sao Francisco River Basin. Geoforum, 64, 292-303. http://dx.doi.org/10.1016/j.geoforum.2015.05.012.

Garrick, D., Anderson, G., Connell, D., \& Pittock, J. (2014). Federal rivers: Managing water in multi-layered political systems. Cheltenham: Edward Elgar Publishing Ltd.

Gillet, V., McKay, J., \& Keremane, G. (2014). Moving from local to State water governance to resolve a local conflict between irrigated agriculture and commercial forestry in South Australia. Journal of Hydrology, 519, 2456-2467. http://dx.doi.org/10.1016/j. jhydrol.2014.08.031.

Hart, B. T. (2016a). The Australian Murray-Darling Basin Plan: Challenges in its implementation (Part 1). International Journal of Water Resources Development, 32(6), 819-834. http:/ /dx.doi.org/10 .1080/07900627.2015.1083847.

Hart, B. T. (2016b). The Australian Murray-Darling Basin Plan: Challenges in its implementation (Part 2). International Journal of Water Resources Development, 32(6), 835-852. http:/ /dx.doi.org/10 $.1080 / 07900627.2015 .1084494$.

Instituto do Meio Ambiente e Recursos Hídricos - INEMA. (2020). Portal de informações sobre os recursos hídricos da Babia. Retrieved in 
April 2020, from http:/ / www.inema.ba.gov.br/ gestao-2/comitesde-bacias/comites/cbh-salitre/

Kirchhoff, C. J., Lemos, M. C., \& Engle, N. L. (2013). What influences climate information use in water management? The role of boundary organizations and governance regimes in Brazil and the U.S. Environmental Science \& Policy, 26, 6-18. http://dx.doi. org/10.1016/j.envsci.2012.07.001.

Lang, D. J., Wiek, A., \& Von Wehrden, H. (2017). Bridging divides in sustainability science. Sustainability Science, 12(6), 875-879. http:/ / dx.doi.org/10.1007/s11625-017-0497-2.

Libanio, P. A. C. (2018). Two decades of Brazil's participatory model for water resources management: from enthusiasm to frustration. Water International, 43(4), 494-511. http:/ / dx.doi.org /10.1080/02508060.2018.1451695.

Machado, E. S., Knapik, H. G., \& Bitencourt, C. C. A. (2019). Considerações sobre o processo de enquadramento de corpos de água. Engenharia Sanitaria e Ambiental, 24(2), 261-269. http:/ / dx.doi.org/10.1590/s1413-41522019181252.

Ménard, C., Jimenez, A., \& Tropp, H. (2018). Addressing the policy-implementation gaps in water services: the key role of meso-institutions. Water International, 43(1), 13-33. http:/ / dx.doi. org/10.1080/02508060.2017.1405696.

Morais, J. L. M., Fadul, É., \& Cerqueira, L. S. (2018). Limites e desafios na Gestão de Recursos Hídricos por Comitês de Bacias Hidrográficas: um estudo nos estados do nordeste do Brasil. Revista Eletrônica de Administração, 24(1), 238-264. http://dx.doi. org/10.1590/1413-2311.187.67528.

Morris, M., \& de Loë, R. C. (2016). Cooperative and adaptive transboundary water governance in Canada's Mackenzie River Basin: status and prospects. Ecology and Society, 21(1), 26. http:/ / dx.doi.org/10.5751/ES-08301-210126.

Neto, S., Camkin, J., Fenemor, A., Tan, P. L., Baptista, J. M., Ribeiro, M., Schulze, R., Stuart-Hill, S., Spray, C., \& Elfithri, R. (2018). OECD principles on water governance in practice: an assessment of existing frameworks in Europe, Asia-Pacific, Africa and South America. Water International, 43(1), 1-30. http:/ / dx.doi.org/10.10 80/02508060.2018.1402650.

Newig, J., \& Fritsch, O. (2009). Environmental governance: participatory, multi-level - and effective? Environmental Policy and Governance, 19(3), 197-214. http://dx.doi.org/10.1002/eet.509.

Nielsen, H. Ø., Frederiksen, P., Saarikoski, H., Rytkönen, A.-M., \& Pedersen, A. B. (2013). How different institutional arrangements promote integrated river basin management. Evidence from the Baltic Sea Region. Land Use Policy, 30(1), 437-445. http://dx.doi. org/10.1016/j.landusepol.2012.04.011.
Organization for Economic Co-operation and Development OECD. (2015a). OECD Principles on Water Governance. OECD Water Governance Programme.

Organization for Economic Co-operation and Development OECD. (2015b). Governança dos Recursos Hídricos no Brasil. Paris, France: OECD Publishing.

Organization for Economic Co-operation and Development OECD. (2018). OECD Water Governance Indicator Framework. OECD Water Governance Programme.

Pahl-Wostl, C. (2017). An evolutionary perspective on water governance: From understanding to transformation. Water Resources Management, 31(10), 2917-2932. http://dx.doi.org/10.1007/ s11269-017-1727-1.

Patrick, M. J., Syme, G. J., \& Horwitz, P. (2014). How reframing a water management issue across scales and levels impacts on perceptions of justice and injustice. Journal of Hydrology, 519, 2475-2482.

Rathwell, K. J., \& Peterson, G. D. (2012). Connecting social networks with ecosystem services for watershed governance: a social-ecological network perspective highlights the critical role of bridging organizations. Ecology and Society, 17(2), 24. http:// dx.doi.org/10.5751/ES-04810-170224.

Ribeiro, J., Lemos, R., Cota, G., Magalhães, A., \& Peron, G. (2018). A abordagem de conflitos pelo uso da água na gestão de recursos hídricos - reflexões a partir do contexto da Bacia do Alto do Rio das Velhas/MG. Caminhos Da Geografia, 19(68), 343-360. http:/ / dx.doi.org/10.14393/RCG196823.

Ribeiro, W. C. (2017a). Shared use of transboundary water resources in la Plata River Basin: utopia or reality? Ambiente \& Sociedade, 20(3), 257-270. http://dx.doi.org/10.1590/1809-4422asocex0005v2032017.

Ribeiro, M. (2017b). A few comments on the Brazilian Water Resource Policy. New Water Policy \& Practice Journal, 3(1), 22-32.

Van Rijswick, M., Edelenbos, J., Hellegers, P., Kok, M., \& Kuks, S. (2014). Ten building blocks for sustainable water governance: an integrated method to assess the governance of water. Water International, 39(5), 725-742. http://dx.doi.org/10.1080/025080 60.2014.951828.

Rossi, R. A., \& Santos, E. (2018). Conflito e Regulação das Águas no Brasil - A experiência do Salitre. Caderno CRH, 31(82), 151-167. http://dx.doi.org/10.1590/s0103-49792018000100010.

Saruchera, D., \& Lautze, J. (2016). Transboundary river basin organizations in Africa: assessing the secretariat. Water Policy, 18(5), 1053-1069. http://dx.doi.org/10.2166/wp.2016.228.

Schulz, C., Martin-Ortega, J., Glenk, K., \& Ioris, A. A. R. (2017). The value base of water governance: A Multi-Disciplinary Perspective. 
Ecological Economics, 131, 241-249. http://dx.doi.org/10.1016/j. ecolecon.2016.09.009.

Siegmund-Schultze, M., Rodorff, V., Köppel, J., \& Sobral, M. (2015). Paternalism or participatory governance? Efforts and obstacles in implementing the Brazilian water policy in a large watershed. Land Use Policy, 48, 120-130. http://dx.doi.org/10.1016/j. landusepol.2015.05.024.

Sørensen, E., \& Torfing, J. (2004). Making governance networks democratic. Roskilde: Roskilde Universitet.

Sousa Júnior, W., Baldwin, C., Camkin, J., Fidelman, P., Silva, O., Neto, S., \& Smith, T. F. (2016). Water: Drought, crisis and governance in australia and brazil. Water, 8(11), 1-21. http:// dx.doi.org/10.3390/w8110493.

Talozi, S., Altz-Stamm, A., Hussein, H., \& Reich, P. (2019). What constitutes an equitable water share? A reassessment of equitable apportionment in the Jordan-Israel water agreement 25 years later. Water Policy, 21(5), 911-933. http://dx.doi.org/10.2166/wp.2019.143.

Taylor, K. S., Longboat, S., \& Grafton, R. Q. (2019). Whose rules? A water justice critique of the OECD's 12 principles on water governance. Water (Switzerland), 11(4), 1-19. http://dx.doi. org/10.3390/w11040809.

Thomas, K. A. (2017). The Ganges water treaty: 20 years of cooperation, on India's terms. Water Policy, 19(4), 724-740. http:/ / dx.doi.org/10.2166/wp.2017.109.
Vera, L. H. A., Montenegro, S. M. G. L., \& Silva, S. R. (2017). Performance of water usage charge in the Nation's domain as a water resource management tool in the São Francisco River basin. RBRH, 22(0), http://dx.doi.org/10.1590/2318-0331.011715171.

Welling, R., Cartin, M., Baykono, D., \& Diallo, O. (2012). Volta River Basin, Ghana and Burkina Faso: Transboundary water management through multi-level participatory governance and community projects. Ghana: IUCN.

Wiek, A., \& Larson, K. L. (2012). Water, People, and Sustainability-A systems framework for analyzing and assessing water governance regimes. Water Resources Management, 26(11), 3153-3171. http:// dx.doi.org/10.1007/s11269-012-0065-6.

Woodhouse, P., \& Muller, M. (2017). Water Governance: An historical perspective on current debates. World Development, 92, 225-241. http://dx.doi.org/10.1016/j.worlddev.2016.11.014.

\section{Authors contributions}

Wanessa Dunga de Assis: Main writer of this article and responsible for the data analysis.

Márcia Maria Rios Ribeiro: Assisted in writing the article and supervised the data analysis procedure.

Simone Rosa da Silva: Reviewed the article and presented suggestions. 